\title{
Effect of Handling Stress on Selected Antioxidants in two Sizes of African Catfish (Clarias Gariepinus)
}

\author{
Momoh M. Y ${ }^{1^{*}}$, Deekae S. N², Gabriel U. $\mathbf{U}^{3}$ \\ Department of Fisheries and Aquatic Environment, Faculty of Agriculture, Rivers State University, Nkpolu- \\ Oroworukwo, Port Harcourt, Nigeria
}

*Corresponding Author: Momoh M. Y, Department of Fisheries and Aquatic Environment, Faculty of Agriculture, Rivers State University, Nkpolu-Oroworukwo, Port Harcourt, Nigeria

\begin{abstract}
Variations in some antioxidants (Catalase, Superoxide dismutase and Glutathione-S-Transferase) in the plasma of juveniles and adult sizes of Clarias gariepinus exposed to three on-farm procedures (starvation, overcrowding and sorting) were determined spectrophotometrically to evaluate oxidative stress in fish exposed to these aquaculture operations. Blood samples were collected from juveniles and adults of catfish exposed to these conditions. The samples were analyzed with Randox test kits. Results from antioxidants analysis showed that the control values of catalase (CAT) superoxide dismutase (SOD) and Glutathione-S-transferase (GST) enzymes activities in the plasma of C.gariepinus (juveniles and adults) from control farm ranged between (0.71 -0.85 Umg/protein); $(0.38-0.50 U m g /$ protein $)$ and $(0.34-0.37 U m g / p r o t e i n)$ respectively. In juvenile and adult fish exposed to these handling stress, the catalase reduced significantly $(P<0.05)$ in both sizes when compared to the control, while Superoxide dismutase and Glutathione transferase values increased significantly. These alterations were more pronounced in the juvenile fish than adult. An indication that juvenile fish were more stressed than adult fish in the rearing facilities.
\end{abstract}

Keywords: Stress, Antioxidants, Catfish, Handling procedures, Aquaculture.

\section{INTRODUCTION}

The commercial catfish industry in Nigeria has grown rapidly in recent years and the intensive production by farmers to meet ever increasing catfish demand has resulted in different operational strategies to enhance optimum performance in different culture systems (Akinrotimi, et al., 2010). This intensive nature of fish farming in Nigeria involves manipulation of fish, which entails some management practices that causes series of physical and physiological disturbances which results in the alterations of some hormones or antioxidants (Ruas et al., 2008). Many aquaculturists assumed that increase in the stocking density is a way to meet the increasing demand for fish, but high stocking densities have many negative effects on the farmed fish, such as aggressive behaviour, reduced feed intake and growth rate, decreased water quality and increase presence of physical injuries (Wall, 2001). The increased stock of fish in the culture medium has also lead to an increased in stress and decreased immune response (Kestin, 1994) From commercial and as well as from animal health point of view, it is important to understand the nature of physiological and metabolic changes that results from handling stress in fish, so that appropriate measures can be carried out to reduce any factor that can reduce the market and flesh value of cultured fish (Pottinger, 2001;Akinrotimi et al., 2009).

Assessment of some biomarkers in aquatic organisms particularly in fish as stress indicator is a validated approach for early warning of stressful conditions during culture operations (Dorval et al., 2005; Gabriel et al., 2011a). During stress conditions, fish change and adapt their metabolic functions (Ahmad et al., 2014; Akinrotimi et al., 2011a). Different fishes respond in different ways to maintain homeostasis during stress and this may involves many physiological changes, and these changes may include osmolality, hormone release, and energetic metabolism (Barton and Iwama, 1991). Barton, (2002), in his work, grouped physiological responses to environmental stressors into two broad groups; primary and secondary response. The primary responses involve the initial neuroendocrine responses which include the release of catecholamines from chromaffin tissue, the stimulation of the hypothalamicpituitary interregnal (HPI) axis culminating in the release of corticosteroid hormones into circulation. The secondary responses include changes in plasma and tissue ion and metabolite levels, 
haematological features, and cellular alterations such as antioxidants (Iwama et al.; 1997; Ashley, 2007). According to Adams, (1990), the response of fish to stress is based on the magnitude and duration of the stress factor.

Antioxidants is very essential in cellular metabolism, it function as link enzymes between the protein and carbohydrate metabolism and also serve as an indicator of stressful conditions in aquatic organisms. A disturbance in the balance between the prooxidants and antioxidants leading to detrimental biochemical and physiological effects is known as oxidative stress (Bagnyukova et al., 2004). This is a harmful condition in which increase in free radical production, decreases and increments in antioxidant levels can lead to potential damage of metabolic cells (Pandey et al., 2013). Thus changes in antioxidant defenses and oxidative damage are used as biomarkers of oxidative stress (Romeo et al., 2015). Studies have shown that fish enter a special anti-stress status during starvation, poor water quality and severe handling procedures in aquaculture, in which their metabolism and physiological functions are altered (Akinrotimi et al., 2011b; Gabriel et al., 2011b). Conversely, fish naturally adopt various survival strategies to maintain their general activities. The immunity and antioxidant ability are the most important physiological functions in fish for avoiding disease (Bebianno et al., 2014). Biomarkers enable integration of toxicant interactions in molecular or cellular targets resulting from exposure to complex mixtures of contaminants (Sole et al., 2009 Akinrotimi et al., 2011c). The enhanced oxidative stress contributes to neuro degeneration. Oxidative stress results from increased production of reactive oxygen species (ROS) and reactive nitrogen species (RNS) mediated by pollutants (Livingstone, 2001). This study is aimed at evaluating the effect of high stocking density (overcrowding), sorting and feed deprivation (starvation) which are some of the on-farm-procedures on the antioxidants levels in $\mathrm{C}$. gariepinus a popular fish for culture in Nigeria.

\section{Materials AND Methods}

\subsection{Location of the Experiment Site/Source of Experimental Fish}

This study was carried out at the Hatchery unit of the African Regional Aquaculture Centre (ARAC) Aluu, Port Harcourt, Rivers State. A total of 120 C.gariepinus comprising 60 adult size (mean total length $32.81 \mathrm{~cm} \pm 3.01 \mathrm{SD}$; mean weight $972.42 \mathrm{~g} \pm 30.01 \mathrm{SD}$ ) and 60 juvenile size (mean length 15.02 \pm 4.77 ; mean weight 309.01 \pm 11.44 ) were procured from African Regional Aquaculture Centre (ARAC) Aluu, Port Harcourt, Rivers State, Nigeria. They were held in circular plastic aquaria in the hatchery unit before they were been subjected to the selected on-farm-procedures (treatments). All the experimental procedures were carried out in the hatchery unit the same day.

\subsection{Experimental Design}

The design of the experiment was based on one way completely randomized design (CRD) with three treatment levels each, namely; Sorting; Overcrowding and Starvation.

\subsection{Experimental Procedure}

The fish were subjected to some common selected handling procedures in aquaculture that result in stress in fish, namely: Sorting; Overcrowding; Starvation (feed deprivation). Blood samples were collected from the kidney of the C.gariepinus by puncturing it using a hypodermic needle. Blood samples were collected from three fish at rest state before and after exposure to these on-farm stresses.

\subsection{Sorting}

Fifteen (15) fish in each size were placed on a sorting table and sorted into three small rectangular plastic aquaria of dimension $0.6 \times 0.3 \times 0.3 \mathrm{~m}^{3}$, five fish per aquaria. Fish were captured and held with a towel. It was restrained physically by covering the head with a towel, placed on a table and blood was collected as indicated above. Three fish out of the five fish in each of the aquaria were sampled at each time and the blood samples collected.

\subsection{Overcrowding}

Ten fish each were stocked each in three small aquaria of dimension $0.3 \times 0.3 \times 0.2 \mathrm{~m}^{3}$. After which, blood samples were collected.

\subsection{Starvation}

Fifteen (15) fish were left inside the aquaria where they were held after harvesting without food for twenty-four (24) hours and were put into three small rectangular aquaria of dimension $0.6 \times 0.3 \times 0.3 \mathrm{~m}^{3}$. Blood samples were collected from three fish each per aquaria 


\subsection{Collection of Blood Samples}

Blood samples were collected from the fish in each exposure. Each blood collection was completed within 5 minutes of fish removal from the culture system. $5 \mathrm{ml}$ samples were drawn once and poured into Eppendorf tubes containing 500U of sodium heparin used as an anticoagulant. The blood samples were put in ice chest box and transported within 6 hours of collection to biochemistry laboratory for analysis.

\subsection{Analytical Procedure}

Blood samples were centrifuged immediately for 15 minutes at $5000 \mathrm{rpm}$.Plasma specimens were separated, pipetted into eppendorf tubes and stored in a refrigerator at $-20^{\circ} \mathrm{C}$ until assayed (Bacanskas et al., 2014). The results were read using a universal microplate reader on a Jenway visible spectrophotometer (Model 6405).

\subsection{Determination of Catalase}

The activity of Catalase in centrifuged plasma was determined spectrophotometrically using the method of Bebianno et al. (2014). In to a centrifuge tube was pipetted $0.5 \mathrm{ml}$ of blood sample treated with $0.5 \mathrm{ml}$ of $10 \%$ TCA. This solution was immediately centrifuged for 15 minutes at 3,000rpm. Supernatant $(0.4 \mathrm{ml})$ was pipetted into two cuvettes. $0.8 \mathrm{ml}$ of $0.4 \mathrm{M}$ Tris buffer at $\mathrm{pH} 8.9$ and $20 \mu \mathrm{l}$ was added to freshly prepared DTNB. Into each cuvette was pipetted $0.76 \mathrm{ml}$ of distilled water and $0.4 \mathrm{ml}$ of $0.059 \mathrm{MH}_{2} \mathrm{O}_{2}$. The mixture was incubated at room temperature to achieve equilibrium. The absorbance was read within 5 minutes in addition to DTNB at $412 \mathrm{~nm}$ against a blank containing $0.5 \mathrm{ml}$ of water.

The activity of Catalase was calculated thus:

Units $/ \mathrm{mg}$ protein $=\underline{\text { Absorbance at } 240 \mathrm{~nm} / \mathrm{min} \times 1000 \mathrm{x} \mathrm{df}}$

43.6

Where : 4.36 is the absorption coefficient of $1 \mathrm{M} \mathrm{H}_{2} \mathrm{O}_{2}$

$1000=$ Catalase activity to hydrolyze $1 \mathrm{mmol}$ of $\mathrm{H}_{2} \mathrm{O}_{2}$ in 1 minute

$\mathrm{df}=$ dilution factor

\subsection{Determination of Superoxide Dismutase (SOD)}

The activity of SOD was determined in the plasma using spectrophotometer (Bacanskas et al., 2014). Two test tubes labelled test (T) and blank (B) were placed in a rack. Into the (T) test tube was pipetted $0.10 \mathrm{ml}$ of buffer, $0.83 \mathrm{ml}$ distilled water, and $0.05 \mathrm{ml}$ of centrifuged plasma. Into the test tube marked (B) was pipetted $0.15 \mathrm{ml}$ of buffer, $0.83 \mathrm{ml}$ of distilled water. The solution was incubated at $25^{\circ} \mathrm{C}$ for 10 minutes. Later, Pyrogallol (reagent) was dissolved in $2 \mathrm{ml} \mathrm{HCL}$ and $0.02 \mathrm{ml}$ of the pyrogallolwas pipetted into test tubes. The solution was mixed immediately by inversion and the record in the increase in absorbance at $340 \mathrm{~nm}$ for approximately 3 minutes was recorded. The reading of sample absorbance was obtained at $420 \mathrm{~nm} /$ minute using the maximum linear rate for both the Test and Blank.

The number of units of SOD in the assay was calculated thus:

Units $/ \mathrm{mg}$ protein $=($ Asorbance at $420 \mathrm{~nm} / \mathrm{min}$ of blank - Absorbance $420 \mathrm{~nm} / \mathrm{min}$ of sample $) X 100$

Absorbance at $420 \mathrm{~nm} / \mathrm{min}$ of blank

\subsection{Determination of Glutathione-S-Transferase}

Glutatransferase concentration was estimated spectrophotometrically according to Dautremepuits 2004). Into one test tube labelled (T) was pipetted $1.00 \mathrm{ml}$ buffer, $0.05 \mathrm{G}-\mathrm{SH}, 0.05 \mathrm{ml} \mathrm{CDNB}$ and $0.05 \mathrm{ml}$ of plasma sample. The solution was mixed immediately by inversion and the increase at absorbance $340 \mathrm{~nm}$ was recorded for approximately 5 minutes. The sample absorbance was read at $340 \mathrm{~nm} / \mathrm{minute}$ using the maximum linear rate for both the Test and the Blank.

The activity of Glutathione-S-Transferase was calculated as follows:

Units $/ \mathrm{mg}$ protein $=($ Absorbance $340 / \mathrm{min}$ Test - Absorbence $340 \mathrm{~nm} / \mathrm{min}$ Blank (1.5) $(\mathrm{df})$

$$
\text { (9.6) (0.05) }
$$

Where $1.15=$ Total volume (in milliliters) of assay

$\mathrm{df}=$ Dilution factor 
9.6 = Millimolar extinction coefficient of Glutathione-1-Chloro-2, 4- Dinitrobenzene conjugate at $340 \mathrm{~nm}$ $0.05=$ Volume (in milliliter) of enzyme used.

\subsection{Data Analysis}

Indices of oxidative stress were analyzed using one-way analysis of variance, (ANOVA) at $5 \%$ level of significance. Post-hoc comparison of significance of variance results gotten from ANOVA was done using DMRT (Duncan Multiple Range Test) tests. These analyses were carried using a computer programme SPSS 10.0.

\section{RESUltS}

Changes in antioxidants in juvenile of $C$. gariepinus exposed to some handling procedures in the culture medium are presented in Table 1. The results revealed that the values of Catalase in all the farms decreased significantly $(\mathrm{P}<0.05)$ among the handling procedures when compared to the control farm. However, the values of Superoxide dismutase (SOD) and Glutathione transferase (GST) were elevated significantly $(\mathrm{P}<0.05)$ when compared to the control (Table 1). In adult fish exposed to some handling procedures as shown in Table 2, the catalase also reduced in all the handling procedures when compared to the control. This reduction was more pronounced in the fish exposed to sorting than other aquaculture operations. Moreover, Superoxide dismutase and Glutathione transferase were equally elevated in other procedures when compared to control. This increase was more noticeable in fish exposed to sorting. Comparatively, the values of catalase (CAT) in adult and juvenile of C.gariepinus exposed to different handling stress are presented in Figure1. The values of CAT were consistently higher in adult when compared to juveniles. However, the highest and the lowest values of CAT during the experiment were in adult fish at the control and sorting respectively. Comparative values of SOD and GST were presented in Figures 2 and 3 respectively. The values of these antioxidants were higher in juveniles than adult fish, except in starvation, where they were within the same range.

Table1. Antioxidants in Plasma of C. gariepinus Juveniles (Mean \pm SD) Exposed to Some Handling Procedures

\begin{tabular}{|l|l|l|l|}
\hline \multirow{2}{*}{ Handling Procedures } & \multicolumn{3}{|c|}{ Antioxidants (Umg/protein) } \\
\cline { 2 - 4 } & Catalase & Superoxide-dismutase & Glutathione-S-transferase \\
\hline Control & $0.71 \pm 0.11^{\mathrm{b}}$ & $0.38 \pm 1.01^{\mathrm{a}}$ & $0.34 \pm 0.10^{\mathrm{a}}$ \\
\hline Starvation & $0.60 \pm 0.01^{\mathrm{a}}$ & $1.02 \pm 0.55^{\mathrm{b}}$ & $0.70 \pm 0.11^{\mathrm{b}}$ \\
\hline Overcrowding & $0.55 \pm 0.01^{\mathrm{a}}$ & $1.43 \pm 0.02^{\mathrm{b}}$ & $0.80 \pm 0.12^{\mathrm{b}}$ \\
\hline Sorting & $0.40 \pm 0.12^{\mathrm{a}}$ & $2.01 \pm 0.22^{\mathrm{c}}$ & $1.93 \pm 0.11^{\mathrm{b}}$ \\
\hline
\end{tabular}

Means within the same column with different superscripts are significantly different $(P<0.05)$

Table2. Antioxidants in Plasma of C. gariepinus Adults (Mean \pm SD) Exposed to Some Handling Procedures

\begin{tabular}{|l|l|l|l|}
\cline { 2 - 4 } & \multicolumn{3}{|c|}{ Antioxidants (Umg/protein) } \\
\cline { 2 - 4 } & Catalase & Superoxide-dismutase & Glutathione-S-transferase \\
\hline Control & $0.85 \pm 0.16^{\mathrm{a}}$ & $0.50 \pm 1.31^{\mathrm{a}}$ & $0.37 \pm 0.27^{\mathrm{a}}$ \\
\hline Starvation & $0.80 \pm 0.32^{\mathrm{a}}$ & $0.97 \pm 0.67^{\mathrm{a}}$ & $0.75 \pm 0.47^{\mathrm{a}}$ \\
\hline Overcrowding & $0.75 \pm 0.02^{\mathrm{a}}$ & $0.68 \pm 2.00^{\mathrm{a}}$ & $0.60 \pm 0.19^{\mathrm{a}}$ \\
\hline Sorting & $0.30 \pm 0.32^{\mathrm{b}}$ & $2.43 \pm 0.22^{\mathrm{b}}$ & $0.98 \pm 0.12^{\mathrm{a}}$ \\
\hline
\end{tabular}

Means within the same column with different superscripts are significantly different $(P<0.05)$

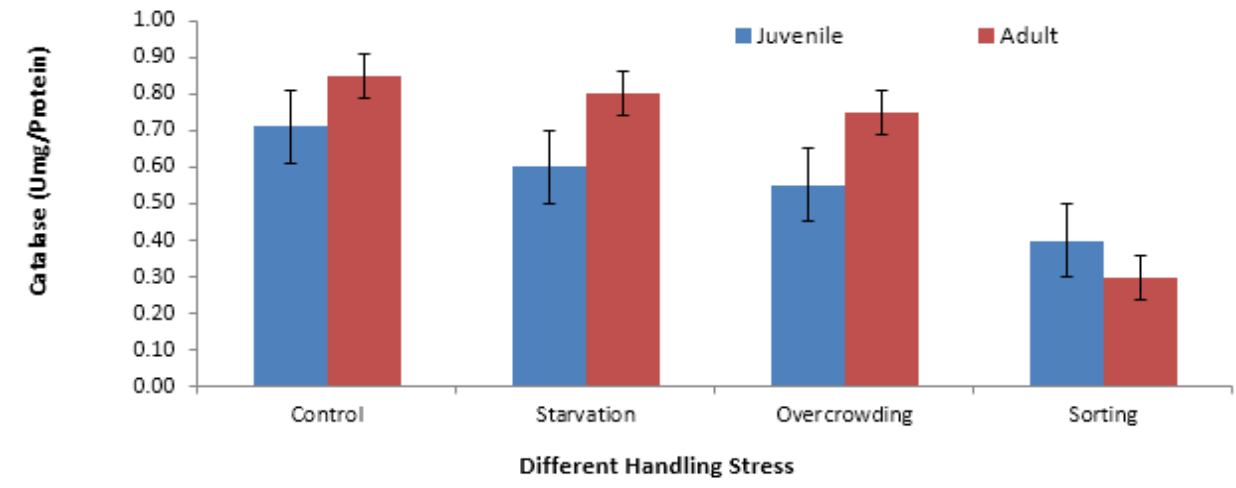

Figure1. Comparative Values of Catalase in C.gariepinus Exposed to Handling Stress 


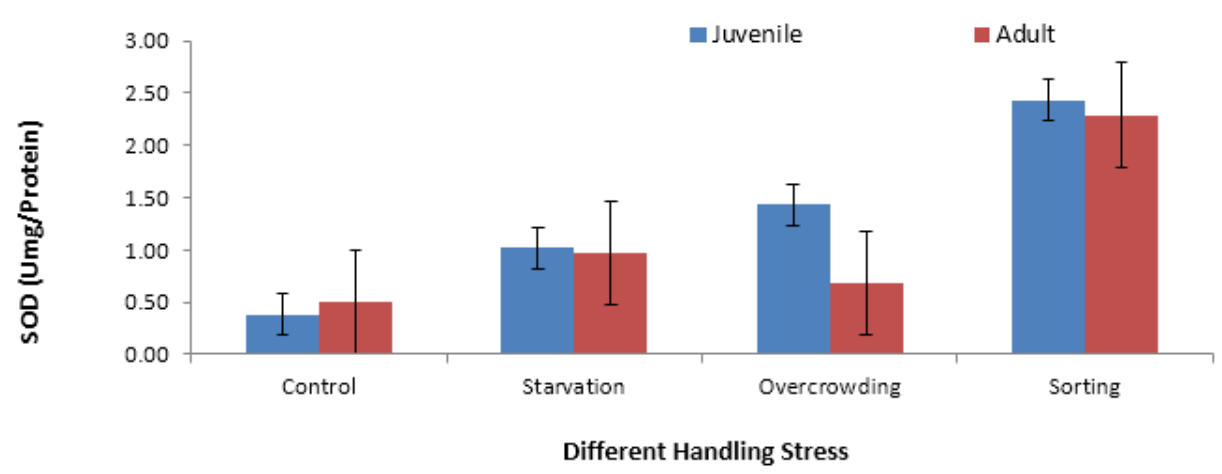

Figure2. Comparative Values of Superoxide dismutase (SOD) in C.gariepinus Exposed to Handling Stress

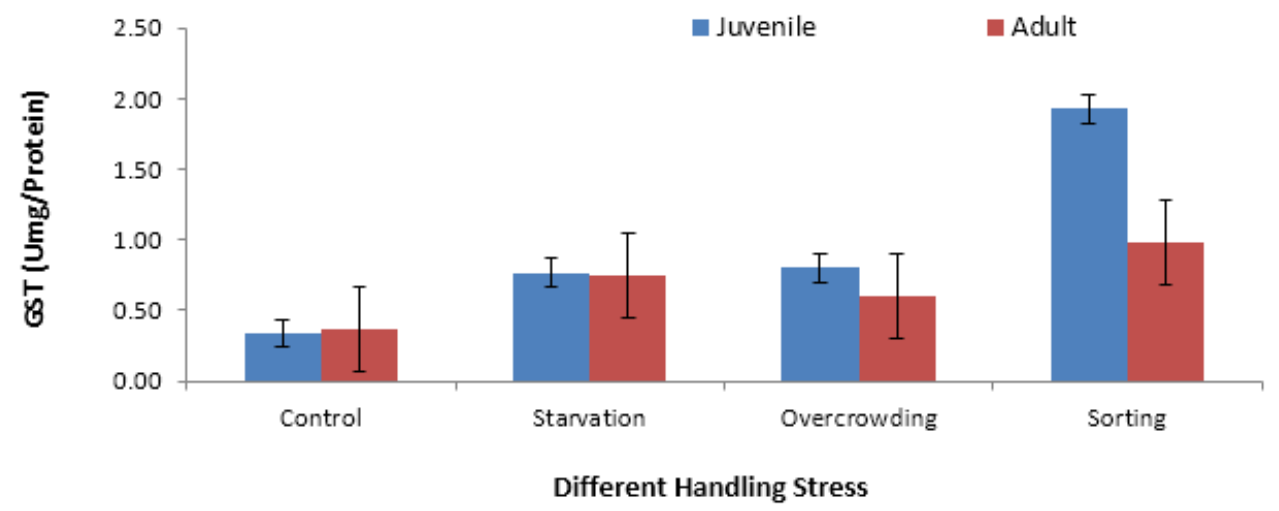

Figure3. Comparative Values of Glutathione-S-transferase (GST) in C.gariepinus Exposed to Handling Stress

\section{DISCUSSION}

The term "antioxidant" is used to define cells' own protective mechanisms. Among the enzymes that comprise this defense system are CAT, SOD and GST, which are responsible for the removal of hydrogen peroxide which is metabolized to oxygen and water (Bacanskas et al., 2014). CAT is the primary enzyme responsible for eliminating the ROS formed during bioactivation of xenobiotics in hepatic tissues (Huang et al., 2007), and the induction of CAT system provides the first line of defense against ROS. CAT activity, however, gradually decreased after exposure to different aquaculture operations and the values obtained were significantly $(\mathrm{P}<0.05)$ lower than those of the control. Decreased CAT activity could stem from decreases in reaction rates resulting from the excess production of hydrogen peroxide. This could have been because of the flux of superoxide radicals, which has been shown to inhibit CAT activity (Ahmad et al., 2014). The procedure dependent decrease in the activity of catalase observed during the present study has also been observed by Almoroth et al. (2008) in rainbow trout exposed to handling stress. Similarly, Evis et al. (2002) observed a decrease in CAT activity in the plasma of Zebrafish subjected to stress. The increase or decrease of enzyme activity is related to the intensity of cellular damage. Catalase depreciation and activation can be considered as a last refuge of antioxidant defense in teleost fish. The catalase role in the antioxidant defense of fish was reported by Porte et al. (2002), based on the information on its activation by hydrogen peroxide at high concentrations. They suggested that catalase normally plays a relatively minor role in hydrogen peroxide catabolism at low rates of peroxide generation, but it becomes indispensable when the rate of hydrogen peroxide production is enhanced, for example, at oxidative stress low intensity, but prolonged effect of spontaneous sources of pollution from aquaculture activities can activate SOD activity in fish tissues.

In this study, elevated SOD and GST activities in combination with the decrease in CAT were observed in the plasma of C.gariepinus exposed to various handling stress. A similar result was observed in the field study of $C$. carpio exposed to handling stress. The results showed that SOD and GST activities were higher, while CAT activities were lower when compared to the control farms (Huang et al., 2007). Moreover, the concerted elevation of SOD and GST activities was equally indicated in the plasma of Atlantic salmon exposed to handling stress (Gatica et al., 2010). Conversely, misbalanced antioxidant activities were reported by Martins et al. (2002) in the various oxidative stress biomarkers in the Oreochromis niloticus exposed to various handling stress in the culture medium. The activation of 
oxidative manifestations leads to the response of antioxidants activation in the expression of genes encoding antioxidant enzymes. Difference in the activity of antioxidant enzymes among farms may be attributed to their activation under mild stress conditions of the location or to their suppression due to strong oxidative damage (Ahmad et al., 2014).

\section{CONCLUSION}

In conclusion, the findings of this study showed that cultured fish species that are affected with environmental stress may be physiologically impaired, and this could be shown on level of various antioxidants. The effect of oxidative stress was more pronounced in fish exposed to sorting. The results of the present investigation led to the conclusion that inherent stress in aquaculture procedures disturbs normal cell functioning and resultant alterations in the fundamental biochemical mechanisms in fish. This opens new avenues for investigations of adaptive mechanisms in animals, particularly in fish, to handling stress during aquaculture operations. In conclusion, to avoid unnecessary stress, fish should be stocked at the appropriate stocking density. Appropriate stocking density prevents the fish from overcrowding which often leads to struggling for food, oxygen and survival which lead to stress. Farmers should also handle the fish carefully during sorting. Also, fish should be feed properly, and should not be made to starve for too long in the culture medium.

\section{REFERENCES}

[1] Adams, S. M (1990). Status and use of biological indicators for evaluating the effects of stress on fish, American Fisheries Society Symposium, 8,112-124.

[2] Ahmad, I.; Pacheco, M. \& Santos M.A. (2014). Enzymatic and Non-enzymatic Antioxidants as an Adaptation to Phagocyte-induced Damage in Anguilla anguilla L. Following in Situ Harbor Water Exposure. Ecotoxicology and Environmental Safety 3 (57):290-302.

[3] Akinrotimi, o. A; Abu, O. M. G; Ansa, E. J; Edun, O. M and George, O. S (2009). Haematological responses of Tilapia guineensis to acute stress. International Journal of Natural and Applied Sciences. (5 (47): 338-343.

[4] Akinrotimi O.A., Abu O.M.G., Agokei E.O., Uedeme-Naa B. (2010). Effects of acclimatization on haematological parameters of Tilapia guineensis. Science World Journal 5(4): 1-4.

[5] Akinrotimi, O.A., Okereke, A.N., \& Ibemere, I.F. (2011a). Studies in plasma glucose as biomakers for stress response in Tilapia guineensis. African Journal of General Agriculture, 7(3), 125 - 130.

[6] Akinrotimi, O.A., Opara, J.Y., \& Ibemere I.F. (2011b). Effects of handling stress on immune functions of Black jaw tilapia, Sarotherodon melanotheron. Nigerian Journal of Fisheries, 8(1),154-158.

[7] Akinrotimi, O.A., Aranyo, A.A., \& Ibemere, I.F. (2011c). Physiological response in Tilapia guineensis subjected to handling stress. Advances in Agriculture science and Engineering Research, 1(2), 34-39.

[8] Almroth BC, Albertsson E, and Förlin LSJ.( 2008). Oxidative stress, evident in antioxidant defenses and damage products, in rainbow trout caged outside a sewage treatment plant. Ecotoxicol Environ Safety.21:5462.

[9] Ashley, C. I. (2007). Stress in Farmed Fish and their effect. Aquic Inter 7, 101-115.

[10] Bacanskas, L.R.; Whitaker, J. \& Di Giulio, R.T. (2014). Oxidative Stress in Two Populations of Killifish (Fundulus heteroclitus) with Differing Contaminant Exposure Histories. Marine Environmental Research, (58): 597-601.

[11] Bagnyukova, T.V.; Chahrak, O.I. and Lushchak, V.I. (2006). Coordinated Response of Goldfish Antioxidant Defenses to Environmental Stress. Aquatic Toxicology, (78) 325-331.

[12] Barton, B. A and Iwama, G. K. (1991). Physiological changes in fish from stress in aquaculture with emphasis on the responses and effects of corticosteroids. Annual Review of Fish Diseases 1:3-26.

[13] Barton, B. A, Schreck, C. B and Fowler, L. G. (1998). Fasting and diet content affect stress-induced changes in plasma glucose and cortisol in juvenile Chinook salmon. The Progressive Fish Culturist. 50:16-22.

[14] Barton, B. A. (2002). Stress in fishes: a diversity of responses with particular circulating corticosteroids. Integ and Comp Biol 42, 517-525.

[15] Bebianno, M. J.; Geret, F.; Hoarau, P.; Serafim, M.A.; Coelho, M. R.; Gnassia-Barelli, M.; Romeo, M.(2014).Biomarkers in Ruditapes decussatus: a potential bioindicator species. Biomarkers (9): 305-310.

[16] Dorval, J.; Leblond, V., Deblois, C. and Hontela, A. (2005). Oxidative Stress and Endocrine Endpoints in White Sucker (Catostomus commersoni) from a River Impacted by Agricultural Chemicals. Environmental Toxicology and Chemistry, (24): 51273-1280. 
[17] Esch, G. W, Hazen, T. C, (1978). Thermal ecology and stress: a case history for red-sore disease in largemouth bass. 331-363. In: energy and environmental stress in aquatic ecosystems. Thorp, J. H and Gibsons, J. W (eds). Technical Information Centre, U. S Department of Energy Conference. 77114.

[18] Evis, J. M; Feist, G. W; Varge, Z. M; Westerfield, M; Kent, M. L and Schreck, $\quad$ C. B. (2002). Wholeblood cortisol is an indicator of crowding stress in adult Zebra fish, Danio rerio. Aquaculture, 258: 565-574.

[19] Gabriel U.U., Akinrotimi O.A., Orluu E.E. (2011b). Haematological characteristics of bloody cockle (Anadara senilis(L), from Andoni flats, Niger Delta, Nigeria. Science world journal. 6 (1) : 144-148.

[20] Gabriel, U.U., Uedeme-Naa, B., \& Akinrotimi, O.A. (2011a). Pollutant induced altered behaviours in fish: A review of selected literature. Journal of Technology and Education in Nigeria (JOTEN), 16(1): 9-23.

[21] Gatica, M. C; Monti, G. E, Knowlrs, T. G and Gallo, C. B (2010). Effects of crowding on blood constituents and flesh quality variables in Atlantic salmon (Salmi salar). Arch. Med. Vet, 42, 187-193.

[22] Huang, D.J.; Zhang, Y.M., Song, G., Long, J., Liu, J.H. and Ji, W.H. (2007). Contaminants induced Oxidative Damage on the Carp Cyprinus carpio Collected from the Upper Yellow River, China. Environmental Monitoring and Assessment. (128): 483-488.

[23] Iwama, G; Pickering A; Sumpter, J and Scherck C, (1997). Fish Stress and Health in Aquaculture. Cambridge University Press 1997.

[24] Kestin S. (1994). Pain and stress in fish. In: RSPCA (Royal Society for the Prevention of Cruelty to Animals). 36pp.

[25] Kono, Y. and Fridovich, I. (2012). Superoxide Radical Inhibits Catalase. The Journal of Biological Chemistry, (257): 57-51.

[26] Livingstone, D.R. (2001). Contaminant-stimulated reactive oxygen species production and oxidative damage in aquatic organisms. Marine Pollution Bulletin, 42: 656-666.

[27] Martins, M. L; Nomora; D. T; Yamagrehi, D. M; Pilarshy, F; Ribeiro, K; Marcells, P and Meldav, C. F (2002). Physiological and haematological response of Oreochromis niloticus (Cichlidae) exposes to single and consecutive stress of captive. Acta. Sci 26(4):449-456.

[28] Pandey, S.; Parvez, S., Sayeed, I., Haque, R., Bin-Hafeez, B. and Raisuddin, S. (2013). Biomarkers of oxidative stress: a comparative study of river Yamuna fish Wallago attu (B1. \& Schn.). Science of the Total Environment, .309, 105-115.

[29] Porte, C., Escartín, E., de la Parra, L.M.G., Biosca, X. and Albaigés, J. (2002). Assessment of Coastal Pollution by Combined Determination of Chemical and Biochemical Markers in Mullus barbatus. Marine Ecology Progress Series, (235): 205-216.

[30] Pottinger, T. G. (2001). Effects of husbandry stress on flesh quality indicators in fish. In: Kestin S, Warriss PD (eds). Farmed fish quality. Blackwell Science, Bristol, England, Pp 145-160.

[31] Reddy, P.K and Leatherland, J. F. (1998). Stress Physiology. In: Leatherland JF, Woo PTK (eds). Fish

[32] Romeo, M., Bennani, N., Gnassia-Barelli, M., Lafaurie, M. and Girard, J.P. (2015). Cadmium and Copper Display Different Responses Towards Oxidative Stress in the Kidney of the Sea Baas Dicentrarchus Labrax. Aquatic Toxicology, (48): 185-194.

[33] Ruas C.B.G., Carvalho, C.S., Araujo, H.S.S., Espindola, E.I.G and Fernandes, M.,(2008). Oxidative stress biomarkers of exposure in the blood of Chichlid species from a metal contaminated river. Ecotoxicology and Environmental safety: 71: 86-93.

[34] Solé, M., Rodríguez, S., Papiol, V., Maynou, F. and Cartes, J.E. (2009). Xenobiotic Metabolism in Marine Fish with Different Trophic Strategies and their Relationship to Ecological Variables. Comparative Biochemistry and Physiology, (149): 83-89.

[35] Stanic, B., Andric, N., Zoric, S., Grubor-Lajsic, G. and Kovacevic, R. (2006). Assessing Pollution in the Danube River Near Novi Sad (Serbia) Using Several Biomarkers in Sterlet (Acipenser ruthenus L.). Ecotoxicology and Environmental Safety, (65): 395-402.

[36] Wall, A. J (2001). Ethical considerations in the handling and slaughter of farmed fish. In: Kestin S, Warriss PD (eds). Farmed fish quality. Blackwell Science. Bristol, England, Pp 108-119.

Citation: Momoh M. Y, et.al, "Effect of Handling Stress on Selected Antioxidants in two Sizes of African Catfish (Clarias Gariepinus)". International Journal of Innovative Studies in Aquatic Biology and Fisheries, 5(3), pp.21-27. http://dx.doi.org/10.20431/2454-7670.0503004

Copyright: (C) 2019 Authors. This is an open-access article distributed under the terms of the Creative Commons Attribution License, which permits unrestricted use, distribution, and reproduction in any medium, provided the original author and source are credited. 